\title{
Amblyomma scalpturatum Neumann, 1906 (Acari: Ixodidae): confirmation in Acre State, Brazil, and description of parasitism in a human
}

\author{
Amblyomma scalpturatum Neumann, 1906 (Acari: Ixodidae): confirmação no Estado do Acre, Brasil, \\ e descrição de parasitismo em um humano \\ André de Abreu Rangel Aguirre ${ }^{1,2 *}$ (D); Vinícius da Silva Rodrigues ${ }^{3}$; Ivaneide Nunes da Costa ${ }^{1,4}$; \\ Marcos Valério Garcia, ${ }^{5,6}$ B Bárbara Guimarães Csordas ${ }^{2,5}$; Renato Andreotti; Jansen Fernandes Medeiros ${ }^{1}$ \\ ${ }^{1}$ Fiocruz Rondônia, Fundação Oswaldo Cruz, Porto Velho, RO, Brasil \\ ${ }^{2}$ Programa de Pós-graduação em Doenças Infecciosas e Parasitárias, Universidade Federal de Mato Grosso do Sul - UFMS, Campo \\ Grande, MS, Brasil \\ ${ }^{3}$ Programa de Pós-graduação em Imunologia e Parasitologia Aplicadas, Universidade Federal de Uberlândia - UFU, Uberlândia, MG, \\ Brasil \\ ${ }^{4}$ Programa de Pós-graduação em Biologia Experimental, Universidade Federal de Rondônia - UNIR, Porto Velho, RO, Brasil \\ ${ }^{5}$ Laboratório de Biologia do Carrapato, Embrapa Gado de Corte, Campo Grande, MS, Brasil \\ ${ }^{6}$ Fundação de Apoio a Pesquisa Agropecuária e Ambiental - FUNDAPAM, Campo Grande, MS, Brasil
}

Received April 12, 2019

Accepted May 30, 2019

\begin{abstract}
Amblyomma scalpturatum is a tick species that is unique to South America. It is commonly associated with the Amazon biome and has been reported in some Brazilian states. This tick species exhibits host specificity: it parasitizes tapirs and suidae. Its role in transmitting pathogens to humans is still unknown. Amblyomma scalpturatum is known to be a human-biting tick; however, there is only one report showing that humans make suitable hosts for this species. The knowledge of tick fauna is lacking in the Acre State. This study collected free-living ticks with the aim of finding new records in Acre State. Collections were carried out in Amazon forest fragments in Rio Branco municipality. An A. scalpturatum specimen was identified and submitted sequencing of the ITS-2 gene. This study presents the first molecular confirmation of $A$. scalpturatum collected in situ in Acre State, North Region, Brazil. This study also presents the first record of a successfully completed feeding by an A. scalpturatum nymph on a human host in the North region of Brazil. Further investigation is needed to ascertain the complete life cycle of this tick species, its seasonality in the environment, and its relationship to pathogens and competence to transmit them.
\end{abstract}

Keywords: Amblyomma scalpturatum, Northern Brazil, humans.

\section{Resumo}

Amblyomma scalpturatum é uma espécie de carrapato que ocorre apenas na América do Sul. Está comumente associada ao bioma da Amazônia e tem sido relatada em alguns estados brasileiros. Esta espécie de carrapato apresenta especificidade a hospedeiros: parasita antas e suídeos. Sua competência em transmitir agentes patogênicos a seres humanos é ainda desconhecida. Amblyomma scalpturatum é também conhecido por picar seres humanos; entretanto, há apenas um relato que evidencie que seres humanos sejam capazes de serem hospedeiros adequados. Ainda existem lacunas no conhecimento sobre a ixodofauna no estado do Acre. Neste estudo foram coletados carrapatos de vida livre com o objetivo de encontrar novos registros para o estado do Acre. Coletas de carrapatos foram realizadas em fragmentos de floresta Amazônica no município de Rio Branco. Um exemplar de A. scalpturatum foi identificado e submetido a sequenciamento do gene ITS-2. Este estudo apresenta a primeira confirmação molecular de $A$. scalpturatum coletado in situ no estado do Acre, região Norte, Brasil. Este estudo também apresenta o primeiro relato de parasitismo completo de uma ninfa de 
A. scalpturatum em um hospedeiro humano na região Norte do Brasil. Mais investigaçóes são necessárias para elucidar o ciclo de vida completo dessa espécie de carrapato, a sazonalidade de seus estádios no meio ambiente, sua relação a agentes patogênicos e competência em transmiti-los.

Palavras-chave: Amblyomma scalpturatum, Norte do Brasil, humanos.

\section{Introduction}

At present, 73 tick species have been described in Brazil: 47 species belong to the Ixodidae family and 26 to the Argasidae family (NAVA et al., 2014; MARTINS et al., 2014, 2016; BARROS-BATTESTI et al., 2015; LABRUNA et al., 2016; WOLF et al., 2016; MICHEL et al., 2017; MUNOZZ-LEAL et al., 2017, 2018). Ticks are the main vectors of several pathogens (JONGEJAN \& UILENBERG, 2004), including the intracellular bacteria Rickettsia rickettsii, which causes Rocky Mountain spotted fever (as it is known in North America) or Brazilian spotted fever (as it is known in Brazil). Brazilian spotted fever is a highly lethal zoonosis that has been reported in Brazil since the 1920s (LABRUNA, 2009).

Acre State is in the North Region of Brazil. This region is totally covered by the Amazon biome and contains a vast amount of biodiversity (CALOURO, 1999). According to Gruhn (2017), information about the ixodofauna in Acre is lacking, however, this author has recently reported the presence of five new tick species in Acre: four of the genus Amblyomma and the species Dermacentor nitens (Neumann, 1897).

In Brazil, Ambyomma scalpturatum Neumann 1906 has been recorded in the states of Amazonas, Pará, Rondônia, Roraima, Mato Grosso, Mato Grosso do Sul and Paraná (ONOFRIO et al., 2006, 2010), and more recent in Acre State (LIMA et al., 2018). This tick species has a predilection to parasitize mammals of the orders Perissodactyla and Tayassuidae during the larval and nymph stages (BARROS-BATTESTI et al., 2006), while tapirs (Tapirus terrestris) are the primary host for adults (LABRUNA et al., $2005 \mathrm{a}, \mathrm{b})$. Nevertheless, $A$. scalpturatum is known to bite humans (GUGLIELMONE \& ROBBINS, 2018; GIANIZELLA et al., 2018; SILVA et al., 2016). Rickettsia belli is of unknown pathogenicity to humans, but its presence in $A$. scalpturatum ticks has been recorded in the Amazon rain forest (LABRUNA et al., 2004).

Since most states covered by the Amazon biome are known to harbor a large number of tick species, information about the ixodofauna in Acre State is almost certainly lacking. This study collected free-living ticks in Acre State with the aim of contributing new records and improving knowledge of the ixodofauna in this region. This study also presents the first record of an $A$. scalpturatum nymph successfully feeding on a human in the Brazilian North region (Rondônia State) - an accidental event experienced by a collaborator on this study.

\section{Materials and Methods}

\section{Tick collections in Acre State}

Two tick collections were performed in 2017 (January and August) in Amazon forest fragments located at Universidade Federal do Acre and along the AC-090 highway "Transacreana", within $45 \mathrm{~km}$ of downtown Rio Branco. Drag flagging and visual inspection of leaves was conducted among bushes lining animal trails within forest fragments. Tick samples were stored in flasks and taken alive to the laboratory. Species identifications were performed under a Leica EZ4 $\mathrm{HD}^{\circledR}$ stereo microscope using taxonomic keys for nymphs (MARTINS et al., 2010) and adults (ONOFRIO et al., 2006). An A. scalpturatum male was identified morphologically and subjected to molecular analysis to confirm species identification. Pictures of this specimen were acquired using Leica LAS EZ ${ }^{\circledR}$ software.

\section{Molecular analysis of $A$. scalpturatum}

The A. scalpturatum male was subjected to DNA extraction using the guanidine isothiocyanate and phenol/chloroform protocol, as described previously (SANGIONI et al., 2005 adapted). Polymerase chain reaction (PCR) used primers ITS-2F and ITS-2R (CSORDAS et al., 2016) to target an rDNA fragment of 649 bp from the Internal Transcribed Spacer 2 (ITS2) gene for further sequencing.

The PCR product was analyzed on a $1.5 \%$ agarose gel containing ethidium bromide, visualized and recorded under ultraviolet light using a transilluminator. The PCR product was sequenced using the Sequencing and Genotyping DNA Platform at the René Rachou Research Center, Oswaldo Cruz Foundation, Belo Horizonte, Brazil. The Sanger method (SANGER et al., 1977) was conducted, in duplicate, using an ABI 3730 (Life Technologies ${ }^{\circledR}$ ) sequencer. The sequences were treated and aligned using the ClustalW algorithm on MEGA 7.0 (KUMAR et al., 2016). The final sequence was deposited in GenBank under access code MH300128.1. The sequence was then aligned and compared to other Amblyomma spp. sequences using the BLASTn tool.

A phylogenetic tree was built to compare the obtained sequence with sequences of Amblyomma spp. on GenBank; this was achieved by applying the Maximum Likelihood method based on the Tamura 3-parameter model (TAMURA, 1992). Initial trees were obtained by applying Neighbor-Join and BioNJ algorithms. All positions containing gaps and missing data were eliminated.

\section{Evaluation of $A$. scalpturatum nymph feeding competence on a human}

An engorged nymph was discovered on the body of a collaborator in this study. The nymph was detached manually and brought to the laboratory. It was incubated under controlled environmental conditions: $28{ }^{\circ} \mathrm{C}$ at $85 \%$ humidity under a $12: 12 \mathrm{~h}$ light-dark cycle. Following incubation and molting, the adult specimen was identified under a stereo microscope using the taxonomic key of Onofrio et al. (2006). 
Since this parasitism occurred accidentally, the origin of the nymph is unknown. However, the nymph's most likely origin is Porto Velho municipality, Rondônia State, because the parasitized individual lives in Porto Velho and takes part in rural activities there. The host affirmed that have not traveled out of the municipality more than 10 days before the nymph was discovered on his body. The accidental nature of the parasitism also made it impossible to measure how long it took the nymph to become fully engorged.

\section{Results}

Two A. scalpturatum adult specimens (one male and one female) were identified among the ticks collected (which included 22 adults, 29 nymphs and 4 larvae). The other identified species were Amblyomma coelebs (Neumann, 1906), Amblyomma naponense (Packard, 1869), Amblyomma oblongoguttatum (Koch, 1844) and Amblyomma ovale (Koch, 1844).

The $A$. scalpturatum male exhibited morphological characteristics in accordance with those previously described for this species: incomplete marginal groove; coxa I with two long unequal spurs smaller than the article length, robust internal spur and thin external spur that reaches but does not cover the next article; coxa IV with one spur; coxas II, III and IV with one small spur; brownish scutum exhibiting deep puctuations and dark elevations with lacking punctuations mainly on median-posterior and lateral fields, indistinct chitinous blades not incised in the festoons (ONOFRIO et al., 2006) (Figures 1 and 2).

The sequenced ITS-2 gene fragment from the $A$. scalpturatum male contained 656 nucleotides (access number $\mathrm{MH} 300128.1$ ), and analysis by BLAST reported 100\% identity with sequences of A. scalpturatum specimens found in Rondônia State, Brazil (access numbers AY619573.1, AY887113.1, AY618575.1) (Figure 3).

The nymph removed from a collaborator's body molted after 27 days of incubation and the resultant adult male was identified as $A$. scalpturatum.

\section{Discussion}

Amblyomma scalpturatum is closely related to two other tick species: Amblyomma latepunctatum (Tonelli-Rondelli), 1939 and Amblyomma incisum (Neumann, 1906) (LABRUNA et al., 2005b). All three species share numerous morphological and ecological features, but a few phenotypic differences make it possible to distinguish among them. One example of a crucial characteristic which distinguish the male specimens of $A$. scalpturatum to the other two species cited above is the chitinous blades not incised in the festoons. This characteristic is extremely variable among male specimens of $A$. latepunctatum, $A$. incisum and $A$. scalpturatum ticks (LABRUNA et al., 2005b) that could present both very long ventral blades or almost indistinct blades, which, especially in the last case, could induce a misidentification among the three species. This misidentification may occur in specimens with indistinct ventral blades, especially in $A$. latepunctatum, which could present more or less blades incised. All the male specimens collected in this study presented indistinct blades (Figure 2). Thus, to testify the species identification, we therefore verified it

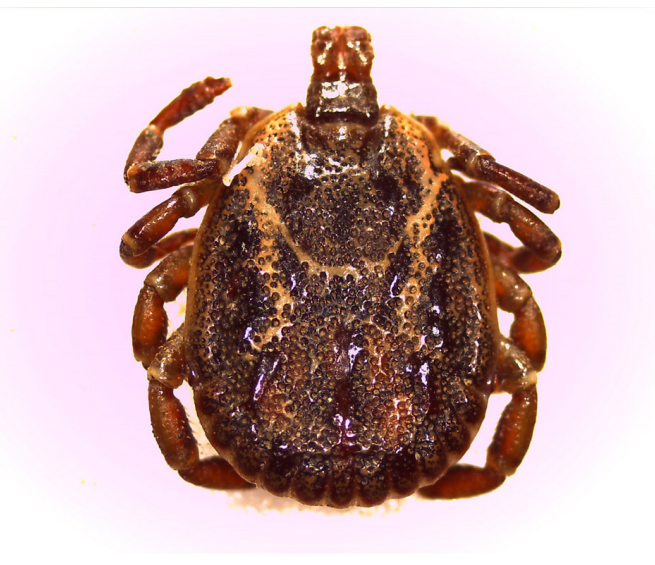

Figure 1. Dorsal view of the male Amblyomma scalpturatum.

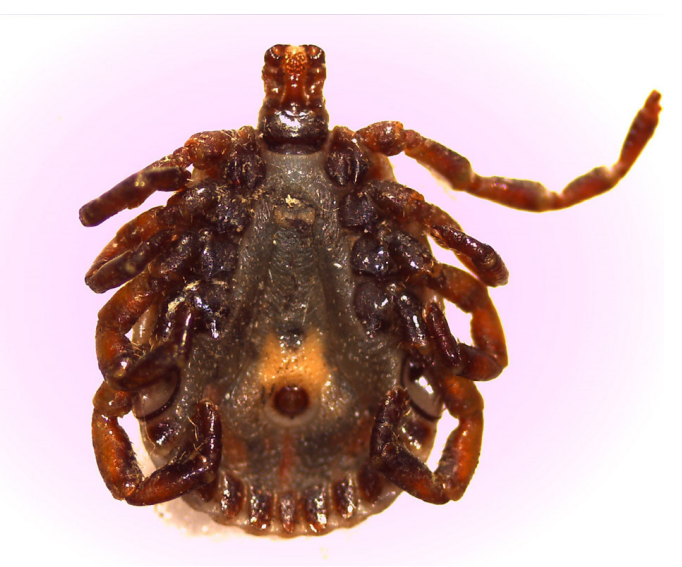

Figure 2. Ventral view of the male Amblyomma scalpturatum.

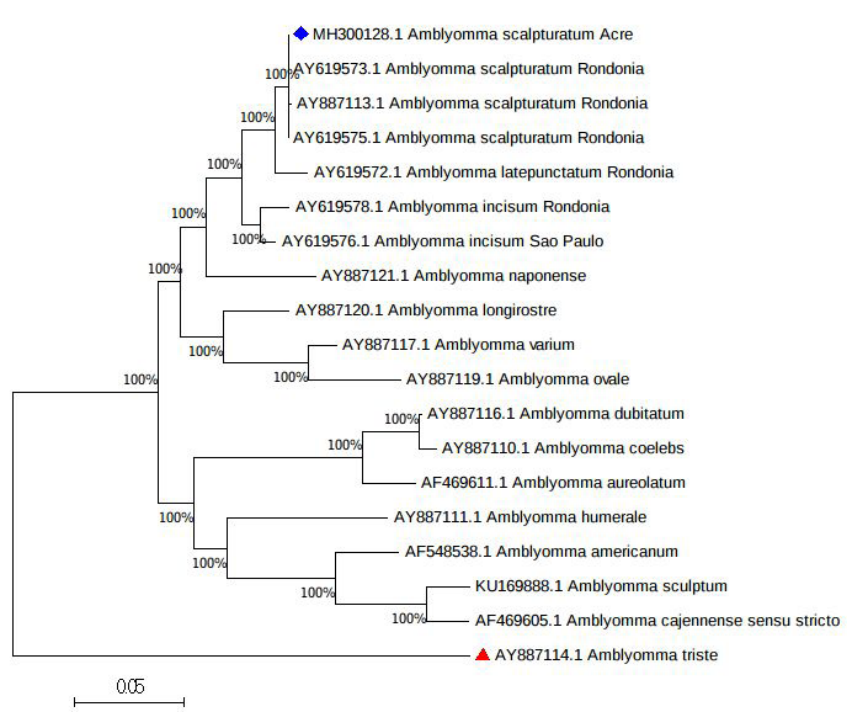

Figure 3. Phylogenetic tree of the Amblyomma scalpturatum ITS-2 partial sequence inferred by the Maximum likelihood method. The sample sequence from this study is marked with a blue rhombus. GenBank access numbers for ITS-2 partial sequences are followed by the corresponding species name. The states of origin follow the sequences from $A$. scalpturatum and the closely related species $A$. latepunctatum and $A$. incisum. The red triangle indicates the outgroup. 
using molecular approaches such as PCR and sequencing of the ITS-2 gene fragment.

Although $A$. scalpturatum already have been recorded in the Acre State (LIMA et al., 2018), this is the first time the presence of A. scalpturatum collected in situ has been confirmed by molecular approaches there. This is noteworthy because, according the explanation above, male specimens with indistinct blades could be misidentified. Furthermore, this feature may be more difficult to be distinguished in conserved specimens, such as ticks from a collection. Figure 3 shows that the sequence obtained in this study was identical to sequences obtained from $A$. scalpturatum specimens collected in the neighboring state of Rondônia, confirming so its presence in the Acre state. Figure 3 also shows that the $A$. scalpturatum specimen in this study is closely related to $A$. latepunctatum and $A$. incisum, as described previously (LABRUNA et al., 2005b).

Amblyomma scalpturatum ticks exhibit ambush behavior, which involves questing for hosts by remaining positioned on leaf edges in dense forest (LABRUNA et al., 2005a, b). This tick species is normally associated with the Amazon rain forest biome in Brazil (LABRUNA et al., 2005a, b; ONOFRIO et al., 2010; MARTINS et al., 2014; SILVA et al., 2016); however, this species has also been reported in other biomes such as Cerrado (Brazilian savannah), Pantanal (marshlands) and Atlantic rain forest (ONOFRIO et al., 2010). Amblyomma scalpturatum is distributed among several Brazilian States where the Amazon biome is present.

Amblyomma scalpturatum is known to be a human-biting tick, but its role in transmitting pathogens to humans remains unknown (SILVA et al., 2016). This tick species has been found carrying $R$. belli (LABRUNA et al., 2004), which means that A. scalpturatum may be a vector of other pathogenic Rickettsia species. This possibility deserves attention and should be further investigated. There is only one report in the literature on the success of $A$. scalpturatum tick in completing its feeding on a human host; this report was performed in 2001 in the state of Mato Grosso (LABRUNA et al., 2005b). So, the present study also reinforces the competence of an $A$. scalpturatum nymph to complete its feeding on a human (a collaborator in this study). When $A$. scalpturatum nymphs feed, the host is exposed to the parasite's saliva for a significant length of time, which suggests that $A$. scalpturatum may be a competent vector of some SFG Rickettsia spp. or other pathogens (SARAIVA et al., 2014), even though $A$. scalpturatum ticks infected with SFG Rickettsia spp. have yet to be reported.

Previously data of the laboratory where this study were carried out reported that an $A$. scalpturatum nymph spent five days to engorge on a mouse, and six to 10 days to engorge on a rabbit (data not published, ethics approval by CEUA-Fiocruz/RO under protocol number 2015/18). By the way, the collaborator that provided us the engorged nymph affirmed that have not traveled more than 10 days before he noted the nymph, so it is presumable that he had acquired it in Porto Velho municipality, state of Rondônia, being the first report in North region of Brazil. The pre-molting period of 27 days reported here is close to the pre-molting periods of three $A$. scalpturatum nymphs that were recorded in our laboratory data: 26 days for one that have fed on one mouse; and 29 and 30 days for two that have fed on one rabbit (data not published).

Although A. scalpturatum is widely distributed throughout the Amazon biome, its life cycle dynamics and its seasonality in the environment remain unknown. Moreover, some human activities (rural employment) increase human exposure to arthropod vectors, which creates favorable conditions for the emergence of the diseases that these vectors transmit (TELFORD \& GOETHERT, 2004).

Even though Amblyomma cajennense sensu lato ticks have not been recorded in the Acre State and surrounding areas, Brazilian spotted fever has been reported in nearby regions of this state (BRASIL, 2018). Therefore, even if $A$. scalpturatum is not yet a proven vector, its geographic distribution needs to be ascertained because it is one of the most common free-living ticks wherever the Amazon biome predominates, and its nymph stage is now stated to be capable of parasitizing humans.

\section{Conclusion}

More information about the spread of potential tick vectors can improve the ability of public health systems and epidemiological programs to control tick-borne diseases. Furthermore, knowledge of the host-parasite relationship is of paramount importance because this relationship determines how pathogens are transmitted from ticks to their hosts. To this end, this study is the first to confirm by DNA sequencing the presence of $A$. scalpturatum in Acre State, Brazil, and the second to document a successfully completed feeding by an $A$. scalpturatum nymph on a human - first in the Rondônia State and the Brazilian North region.

\section{Acknowledgements}

We are grateful to André Júlio do Nascimento for providing us with the engorged nymph. The research was supported by Coordenação de Aperfeiçoamento de Pessoal de Nível Superior - CAPES, Conselho Nacional de Desenvolvimento Científico e Tecnológico - CNPq, Fundação de Apoio a Pesquisa Agropecuária e Ambiental - FUNDAPAM, Campo Grande, MS, Brasil. Fundação de Amparo a Pesquisa do Estado de Rondônia - FAPERO-RO and Fiocruz - Rondônia.

\section{References}

Barros-Battesti DM, Arzua M, Bechara GH. Carrapatos de importância médico-veterinária da Região Neotropical: um guia ilustrado para identificação de espécies. São Paulo: Vox/ICTTD-3/Butantan; 2006.

Barros-Battesti DM, Landulfo GA, Luz HR, Marcili A, Onofrio VC, Famadas KM. Ornithodoros faccinii n. sp. (Acari: Ixodida: Argasidae) parasitizing the frog Thoropa miliaris (Amphibia: Anura: Cycloramphidae) in Brazil. Parasit Vectors 2015; 8(1): 268. http://dx.doi.org/10.1186/ s13071-015-0877-3. PMid:25963542.

Brasil. Ministério da Saúde. Secretaria de Vigilância em Saúde - SVS. Sistema de informação de agravos de notificação: Sinan Net [online]. Brasília: 
SVS; 2018 [cited 2018 July 10]. Available from: http://tabnet.datasus. gov.br/cgi/tabcgi.exe?sinannet/cnv/febremaculosabr.def

Calouro AM. Riqueza de mamíferos de grande e médio porte do Parque Nacional da Serra do Divisor (Acre, Brasil). Rev Bras Zool 1999; 16(Suppl 2): 195-213. http://dx.doi.org/10.1590/S0101-81751999000600020.

Csordas BG, Garcia MV, Cunha RC, Giachetto PF, Blecha IMZ, Andreotti R. New insights from molecular characterization of the tick Rhipicephalus (Boophilus) microplus in Brazil. Electron. Rev Bras Parasitol Vet 2016; 25(3): 317-326. http://dx.doi.org/10.1590/S1984-29612016053. PMid:27579530.

Gianizella SL, Martins TF, Onofrio VC, Aguiar NO, Gravena W, Nascimento CAR, et al. Ticks (Acari: Ixodidae) of the state of Amazonas, Brazil. Exp ApplAcarol 2018; 74(2): 177-183. http://dx.doi.org/10.1007/ s10493-018-0221-7. PMid:29383533.

Gruhn KD. Infecção por Rickettsia spp. (Rickettsiaceae) em carrapatos (Acari:Ixodidae) e capivaras (Hydrochoerus hydrochaeris Linneaus, 1766) (Rodentia: Caviidae) de vida livre no Estado do Acre, Brasil, Amazonia Ocidental [thesis]. Rio Branco: Universidade Federal do Acre; 2017.

Guglielmone AA, Robbins RG. Tick species found feeding on humans. In: Guglielmone AA, Robbins RG, editors. Hard ticks (Acari: Ixodida: Ixodidae) parasitizing humans: a global overview. 1st ed. London: Springer; 2018. 205 p. http://dx.doi.org/10.1007/978-3-319-95552-0_1

Jongejan F, Uilenberg G. The global importance of ticks. Parasitology 2004;129(1 Suppl): 3-14. http://dx.doi.org/10.1017/S0031182004005967. PMid:15938502.

Kumar S, Stecher G, Tamura K. MEGA7: molecular evolutionary genetics analysis version 7.0 for bigger datasets. Mol Biol Evol 2016; 33(7): 18701874. http://dx.doi.org/10.1093/molbev/msw054. PMid:27004904.

Labruna MB. Ecology of Rickettsia in South America. Ann N Y Acad Sci 2009; 1166(1): 156-166. http://dx.doi.org/10.1111/j.17496632.2009.04516.x. PMid:19538276.

Labruna MB, Whitworth T, Bouyer DH, McBride J, Camargo LMA, Camargo EP, et al. Rickettsia bellii and Rickettsia amblyommii in Amblyomma ticks from the State of Rondônia, Western Amazon, Brazil. J Med Entomol 2004; 41(6): 1073-1081. http://dx.doi.org/10.1603/00222585-41.6.1073. PMid:15605647.

Labruna MB, Jorge RSP, Sana DA, Jácomo ATA, Kashivakura CK, Furtado MM, et al. Ticks (Acari: Ixodida) on wild carnivores in Brazil. Exp Appl Acarol 2005a; 36(1-2): 149-163. http://dx.doi.org/10.1007/ s10493-005-2563-1. PMid:16082932.

Labruna MB, Keirans JE, Camargo LMA, Ribeiro AF, Soares RM, Camargo EP. Amblyomma latepunctatum, a valid tick species (Acari: Ixodidae) long misidentified with both Amblyomma incisum and Amblyomma scalpturatum. J Parasitol 2005b; 91(3): 527-541. http://dx.doi.org/10.1645/GE-446R. PMid:16108543.

Labruna MB, Nava S, Marcili A, Barbieri ARM, Nunes PH, Horta MC, et al. A new argasid tick species (Acari: Argasidae) associated with the rock cavy, Kerodon rupestris Wied-Neuwied (Rodentia: Caviidae), in a semiarid region of Brazil. Parasit Vectors 2016; 9(1): 511. http://dx.doi. org/10.1186/s13071-016-1796-7. PMid:27655282.

Lima MA, Martins TF, Muñoz-Leal S, Guilherme E, Ogrzewalska M, Labruna MB. Ticks and tick-associated spotted fever group Rickettsia from birds in the Southwestern Brazilian Amazon. Rev Colomb Cienc Pecu 2018; 31(1): 26-35. http://dx.doi.org/10.17533/udea.rccp.v31n1a04.
Martins TF, Barbieri ARM, Costa FB, Terassini FA, Camargo LMA, Peterka CRL, et al. Geographical distribution of Amblyomma cajennense (sensu lato) ticks (Parasitiformes: Ixodidae) in Brazil, with description of the nymph of $A$. cajennense (sensu stricto). Parasit Vectors 2016; 9(1): 186. http://dx.doi.org/10.1186/s13071-016-1460-2. PMid:27036324.

Martins TF, Fecchio A, Labruna MB. Ticks of the genus Amblyomma (Acari: Ixodidae) on wild birds in the Brazilian Amazon. Syst Appl Acarol 2014; 19(4): 385-392. http://dx.doi.org/10.11158/saa.19.4.1.

Martins TF, Onofrio VC, Barros-Battesti DM, Labruna MB. Nymphs of the genus Amblyomma (Acari: Ixodidae) of Brazil: Descriptions, redescriptions, and identification key. Ticks Tick Borne Dis 2010; 1(2): 75-99. http://dx.doi.org/10.1016/j.ttbdis.2010.03.002. PMid:21771514.

Michel T, Souza U, Dall'Agnol B, Webster A, Peters F, Christoff A, et al. Ixodes spp. (Acari: Ixodidae) ticks in Rio Grande do sul state, Brazil. Syst Appl Acarol 2017; 22(12): 2057-2067. http://dx.doi.org/10.11158/ saa.22.12.3.

Muñoz-Leal S, Toledo LF, Venzal JM, Marcili A, Martins TF, Acosta ICL, et al. Description of a new soft tick species (Acari: Argasidae: Ornithodoros) associated with stream-breeding frogs (Anura: Cycloramphidae: Cycloramphus) in Brazil. Ticks Tick Borne Dis 2017; 8(5): 682-692. http:// dx.doi.org/10.1016/j.ttbdis.2017.04.015. PMid:28506539.

Muñoz-Leal S, Faccini-Martínez ÁA, Costa FB, Marcili A, Mesquita ETKC, Marques EP Jr, et al. Isolation and molecular characterization of a relapsing fever Borrelia recovered from Ornithodoros rudis in Brazil. Ticks Tick Borne Dis 2018; 9(4): 864-871. http://dx.doi.org/10.1016/j. ttbdis.2018.03.008. PMid:29571703.

Nava S, Beati L, Labruna MB, Cáceres AG, Mangold AJ, Guglielmone AA. Reassessment of the taxonomic status of Amblyomma cajennense (Fabricius, 1787) with the description of three new species, Amblyomma tonelliae n. sp., Amblyomma interandinum n. sp. and Amblyomma patinoi n. sp., and reinstatement of Amblyomma mixtum Koch, 1844, and Amblyomma sculptum Berlese, 1888 (Ixodida: Ixodidae). Ticks Tick Borne Dis 2014; 5(3): 252-276. http://dx.doi.org/10.1016/j.ttbdis.2013.11.004. PMid:24556273.

Onofrio VC, Labruna MB, Pinter A, Giacomin FG, Barros-Battesti DM. Comentários e chaves para as espécies do gênero Amblyomma. In: Barros-Battesti DM, Arzua M, Bechara GH, editors. Carrapatos de importância médico-veterinária da Região Neotropical: um guia ilustrado para identificação de espécies. São Paulo: Vox/ICTTD-3/Butantan; 2006. p. 53-113.

Onofrio VC, Arzua M, Labruna MB, Faccini JLH, Barros-Battesti DM. First record of Amblyomma scalpturatum Neumann (Acari: Ixodidae) in the states of Paraná and Roraima, Brazil. Neotrop Entomol 2010; 39(3): 451-453. http://dx.doi.org/10.1590/S1519-566X2010000300023. PMid:20676523.

Sanger F, Nicklen S, Coulson AR. DNA sequencing with chain-terminating inhibitors. Proc Natl Acad Sci USA 1977; 74(12): 5463-5467. http:// dx.doi.org/10.1073/pnas.74.12.5463. PMid:271968.

Sangioni LA, Horta MC, Vianna MCB, Gennari SM, Soares RM, Galvão MAM, et al. Rickettsial infection in animals and Brazilian spotted fever endemicity. Emerg Infect Dis 2005; 11(2): 265-270. http://dx.doi. org/10.3201/eid1102.040656. PMid:15752445.

Saraiva DG, Soares HS, Soares JF, Labruna MB. Feeding period required by Amblyomma aureolatum ticks for transmission of Rickettsia rickettsii to vertebrate hosts. Emerg Infect Dis 2014; 20(9): 1504-1510. http:// dx.doi.org/10.3201/eid2009.140189. PMid:25148391. 
Silva TKS, Blanco CM, Lemos ERS, Ogrzewalska M. Notes on parasitism and screening for microorganism of ticks Amblyomma (Acari : Ixodidae), Amazon, Brazil. Brazil. Virus Rev Res 2016; 21(2): 41-44. http://dx.doi. org/10.17525/vrrjournal.v21i2.277.

Tamura K. Estimation of the number of nucleotide substitutions when there are strong transition-transversion and $\mathrm{G}+\mathrm{C}$-content biases. Mol Biol Evol 1992; 9(4): 678-687. PMid:1630306.
Telford SR 3rd, Goethert HK. Emerging tick-borne infections: Rediscovered and better characterized, or truly 'new'? Parasitology 2004;129(1 Suppl): 301-327. http://dx.doi.org/10.1017/S0031182003004669. PMid:15940821.

Wolf RW, Aragona M, Muñoz-Leal S, Pinto LB, Melo ALT, Braga IA, et al. Novel Babesia and Hepatozoon agents infecting non-volant small mammals in the Brazilian Pantanal, with the first record of the tick Ornithodoros guaporensis in Brazil. Ticks Tick Borne Dis 2016; 7(3): 449-456. http:// dx.doi.org/10.1016/j.ttbdis.2016.01.005. PMid:26782931. 